\title{
Mapping 'wild zones' of globalisation: on private actors and the rule of law
}

\author{
Chantal Mak* \\ Professor of private law, in particular fundamental rights and private law, Amsterdam Centre for Transformative Private Law \\ (ACT), University of Amsterdam, The Netherlands \\ *Corresponding author. E-mail: c.mak@uva.nl
}

\section{Everybody wants to rule the world}

While private corporations have become increasingly influential in the global economy, a comprehensive legal framework for their activities is missing. Although international and regional legal instruments may govern some aspects of, for instance, international investments and the supply of goods and services, there is no overarching structure for assessing the impact of large-scale private projects. In the absence of such a comprehensive framework, specific rules of private law allow profit-seeking companies to expand their activities on an economic basis, mostly without having to heed social concerns (Pistor, 2019). This is particularly problematic insofar as multinational companies have obtained power to set the rules for their engagement with states, organisations and individuals, for instance in the form of transnational investment contracts. Given the fragmented nature of the legal sphere in which such contracts are elaborated and performed, those who face the harmful consequences of such investments may not be able to participate in decision-making processes. The contracts remain in 'wild zones' of globalisation (Fraser, 2014, p. 150), where powerful private companies rule. ${ }^{1}$

Kinnari Bhatt and Jennifer Lander offer important insights into the manners in which private actors shape the legal framework within which they conduct their transnational business. Providing an in-depth analysis of the dynamics of negotiating investment contracts, Bhatt shows how indigenous peoples' land rights are 'lost in the space of international law' (Bhatt, 2020, p. 77). Given the disconnect between the primarily national rules of contract law that govern business transactions and international human rights standards that are mostly directed at states and not at private actors, the law facilitates rather than curbs corporate power. In a similar vein, Lander's study of Mongolia's mining-governance regime makes visible how the preferences of foreign investors influence the process of decision-making on the extraction of natural resources (Lander, 2020). Whereas the state may inadvertently adopt market-based rationales of governance when contracting with international investors, citizens who are affected by extractive practices have far less influence. Their voices are only heard in the decision-making process through the mediation of donor agencies and nongovernmental organisations (Lander, 2020, p. 249). Both Bhatt and Lander, thus, show how transnational investment contracts change the law and governance frameworks through which citizens can hold public authorities as well as private actors accountable for infringements of fundamental rights. The power of private capital shapes the legal framework that governs it and, thus, obtains a constitutional dimension.

This contribution addresses the question of how the transnational legal order should be understood if legal accountability of private actors in transnational investments is to be acknowledged. In particular, it looks into the possibilities for participation in decision-making processes of individuals and communities who are harmed by development projects. In line with Bhatt's and Lander's work, it

\footnotetext{
${ }^{1}$ Hence, the title of this section, which is borrowed from the well-known Tears for Fears song.

( $)$ The Author(s), 2021. Published by Cambridge University Press. This is an Open Access article, distributed under the terms of the Creative Commons Attribution licence (http://creativecommons.org/licenses/by/4.0/), which permits unrestricted re-use, distribution, and reproduction in any medium, provided the original work is properly cited.
} 
is submitted that unmoderated power of profit-oriented companies is problematic in light of rule-of-law standards, especially since it reduces equal participation of less powerful actors. Therefore, a rethinking of the order of transnational law is required (section 2). Taking inspiration from the work of Nancy Fraser, it is submitted that the wild zones in which multinational companies conduct their business need to be included in the conceptualisation of a transnational legal order. From a theoretical perspective, however, the imagination of such an overarching regime is not without danger, as it might emphasise the capitalist premises of the current world order (section 3). For this reason, studies that, like Lander's and Bhatt's books, map the spaces that are left open between overarching international standards and national contract-law regimes are highly necessary. They provide new insights into the ordering of transnational law and the manners in which strong private actors shape legal frameworks to their profit-making advantage. At the same time, they indicate where changes may be made to limit companies' power and strengthen the voices of other private actors. Such mapping exercises, in conclusion, provide starting points for a bottom-up alignment of transnational governance regimes with rule-of-law standards (section 4).

\section{The rule of law and transnational contracts}

In their Introduction to this Special Issue, Kinnari Bhatt, Jennifer Lander and Sanne Taekema challenge established understandings of the rule of law that emphasise the safeguards provided against 'the exercise of arbitrary power by requiring legal foundations for any decision or action by a public authority that impacts the rights and expectations of individuals' (Bhatt et al., in this issue, section 2.1). They convincingly argue that a traditional view on the rule of law may not be suited for transnational development projects. On the one hand, this rule-of-law perspective benefits businesses, insofar as they may claim freedom from state intervention in their contractual relationships and property rights. On the other hand, such companies cannot be held accountable for their interference with the rights of others, most importantly individuals and communities who are harmed by development projects (Bhatt et al., in this issue, section 2.1). In order to reduce the risks of arbitrary decision-making for all, the rule of law should encompass not only public authorities, but also powerful private actors.

In their books, both Bhatt and Lander relate the transformative power of private companies to theories of 'new constitutionalism'. Bhatt's research makes visible how contractual, policy and behavioural mechanisms strengthen the influence of investment companies on law-making processes and 'impact upon the availability, clarity, predictability and fairness of citizens' basic services in energy, infrastructure and even legal remedy' (Bhatt, 2020, p. 20). She underlines that transnational development projects thus raise questions of a constitutional nature. Lander further elaborates on this constitutional-theoretical dimension on the basis of her case-study on the Mongolian mining-governance regime. The influence of foreign investors, it is submitted, results in 'constitution-like' processes, insofar as these actors have the power to impose norms deriving from international investment and commercial law on national law and governance structures (Lander, 2020, pp. 244-245).

Such dynamics are not adequately addressed in an understanding of the rule of law that focuses on public authorities alone. In traditional conceptualisations, companies are only considered as possible victims of states' rule-of-law breaches. Rather than addressing their own conduct, this may even help companies to push for more protective investment laws (Bhatt et al., in this issue, section 2.2). The possible infringements of rule-of-law standards by foreign-investment companies themselves remain invisible in such accounts. Bhatt, Lander and Taekema, therefore, submit that the notion of the rule of law should be expanded in order to 'reveal and assess the arbitrary impacts of transnational exercises of private power on public legal rights and expectations' (in this issue, section 1).

Although I mostly agree with this view, some further observations may be made. An expansion of the rule of law to private actors, in my opinion, requires at least two steps to be taken. In the first place, it has to be accepted that private actors may in similar manners as public authorities affect participation, access to justice and human rights protection. They thus have the power to shape and change the legal framework that governs transnational investments according to their own profit-oriented 
preferences. For scholars in the field of human rights and private law, this is certainly not the most problematic aspect of the claim. In fact, the acceptance of human-rights argumentation in private law strongly relies on the idea that private actors may equally interfere with human rights, sometimes even more intensely than public authorities do. ${ }^{2}$ Accordingly, my further commentary will depart from the assumption that the power of strong private companies should be brought under the rule of law to safeguard protection for all.

A second step, which raises more questions, concerns the way in which the legal framework for transnational development projects is envisaged. Explicitly taking distance from theories that conceptualise transnational law in terms of new 'spheres' or 'scales', Bhatt, Lander and Taekema draw on literature that addresses transnational legality as cross-border ordering processes (in this issue, section 2.2). Building on the work of, among others, Cutler, Shaffer and Zumbansen, they hold that 'the transnational cannot really be seen as a separate legal sphere, but should rather be regarded as a space in which various forms of law and regulation - public, private, hard, soft, national, international - interact' (in this issue, section 2.2). Social relations are mediated beyond and through national states and 'produce the conditions through which "global" capitalist expansion becomes possible' (Lander, 2020, p. 6; Bhatt, 2020, p. 20). The ordering process implied by the rule of law may be located on a metalevel. As proposed by Rajah, the rule of law then provides the umbrella under which law, legitimacy and conceptions of legality can be managed and regulated in the realm of the transnational (Rajah, 2015 , p. 343).

This conceptualisation of transnational ordering in terms of the rule of law is not uncontroversial. The question has, for instance, been raised whether a metaconcept of the rule of law would encompass all forms of transnational legal ordering or only those that have emerged in Western legal development (Halliday and Shaffer, 2015, p. 495). Furthermore, it is not clear whether other ordering processes can be identified that work on a similar metalevel (Halliday and Shaffer, 2015, p. 495). While these are highly relevant points, they deserve a more elaborate and nuanced analysis than is possible here and can, therefore, not be fully elaborated. At the risk of stating the obvious, it may suffice for now to observe that care should be taken when looking for improvements in the transnational legal landscape from a particular conceptual point of view.

Still, assuming that at least some of the elements embodied in a broad rule-of-law concept apply without reservations to all processes of transnational ordering, my focus lies on the inclusion of so-called wild zones of globalisation under the rule-of-law umbrella. In line with the introductory notes provided by Bhatt, Lander and Taekema, the question is how arbitrary private power can be contained through transnational law. How can powerful private actors be tamed in spaces in which they can seemingly develop their profit-oriented projects without taking into account the detrimental effects on others? One rule-of-law element that is served by including wild zones of globalisation in a conceptualisation of the transnational legal order is that of the possibilities for affected individuals and communities to participate in decision-making processes. Who should have a say in decisionmaking process on transnational investments and how do views on transnational legal ordering affect the demarcation of the relevant group?

\section{Understanding 'wild zones' in transnational private law}

In contrast to the approach that Bhatt, Lander and Taekema suggest, I would like to submit that inspiration may be found in theories on the 'scales' or 'spheres' in which justice expresses itself in a transnational setting. Such theories may arguably not provide the best descriptive account of the legal framework for transnational investments, especially given the unlikeliness of a world government developing anytime soon. They do, however, offer a background against which to consider the ways in which institutional decision-making structures may be improved for individuals and communities who currently find themselves in wild zones of globalisation.

\footnotetext{
${ }^{2}$ E.g. Colombi Ciacchi (2006, p. 178); Collins (2014, p. 36), with some reservations.
} 
In her influential work on the reimagination of political space in a globalising world, Nancy Fraser makes a distinction between the 'what', 'who' and 'how' of justice (Fraser, 2008, pp. 12-29). Globalisation has urged theorists to look beyond the Westphalian frame, in which the nation state was the site for addressing questions of justice among fellow citizens in national democratic processes (Fraser, 2008, pp. 12-14). Besides first-order questions of justice on, for instance, matters of redistribution, second-order questions have arisen on the proper frame or scale for assessing such first-order issues (Fraser, 2008, p. 15). In regard to the inclusion in decision-making processes, there is no longer one frame in which each individual participates, but a multiplicity of partly overlapping governance structures - local, national, regional and global (Fraser, 2008, p. 66). Letting go of the Westphalian, state-centred frame, Fraser holds that all who are subjected to a given governance structure are entitled to participate on a par with other subjects in interactions within that structure (Fraser, 2008, pp. 60, 65). The 'who' of justice should, accordingly, be defined on the basis of what may be called the allsubjected principle (Fraser, 2008, pp. 65-66). ${ }^{3}$

Fraser's approach to inclusiveness of decision-making resonates with views on multilevel governance in the area of law in which I conduct most of my research: that of European private law. This field may be understood as comprising the rules and principles that govern legal relationships between private actors in Europe. Hence, it combines the national private laws of EU Member States with rules and principles deriving from EU law. Given the different backgrounds and aspirations of national and European law, European private law is not always fully coherent or complete. Furthermore, an ongoing academic debate addresses the democratic and justice deficits of European law, namely the shortcomings in the process of involving European citizens in the enactment of new legislation and defining shared views on justice, and how to mend them (Hesselink, 2015; Caruso, 2015). The study of European private law thus raises many of the framing questions for which Fraser seeks to provide answers.

Given the relatively high rule density of most European jurisdictions and the EU, one might think that the field of European private law encompasses fewer wild zones than the transnational areas discussed by Lander and Bhatt. Many specific interactions are quite heavily regulated, which limits the space for private actors to arbitrarily wield their power. Examples include the regulation of consumer (sales) contracts (e.g. Reich et al., 2014; Luzak and Mak, 2014), housing (Domurath and Mak, 2020; Van Duin, 2017) and air quality (Kas, 2019). All of these matters are governed by a 'hybrid' constellation of specific EU rules and national private laws (Kas, 2019, p. 351; Tuori, 2014, p. 14).

Despite this impression, nevertheless, on a closer look, examples may certainly be found of zones of European private law in which private power seems equally unlimited as in the cases of transnational investments that Lander and Bhatt present. This became apparent, for instance, in the series of housing cases that arose in the wake of the economic and financial crisis of 2008 (Van Duin, 2017; Józon, 2020). Many mortgage contracts in countries such as Spain and Hungary had almost unilaterally been dictated by banks and contained terms that were very disadvantageous to homeowners. The cases seemed to fall through the cracks in the system of European private law, insofar as national procedural laws allowed banks to go ahead with enforcement and eviction proceedings based on such one-sided contracts. Only through the inventiveness of national judges dealing with these cases were the wild zones tamed: in dialogue with the Court of Justice of the EU (CJEU), the national courts managed to establish that procedural impediments could not stand in the way of granting homeowners effective protection against unfair terms in mortgage contracts. ${ }^{4}$

While it may be said that the CJEU brought the housing cases under the framework of EU contract law, it is still debated to what extent the individuals whose cases are determined by this regime are fully

\footnotetext{
${ }^{3}$ Fraser distinguishes the all-subjected principle from the all-affected principle, which refers to all those affected by justice issues, and argues in favour of the more restrictive notion of subjectedness. Since the discussion of the two principles is of lesser relevance for the points made in this contribution, it will not be further elaborated here.

${ }^{4}$ Case C-415/11, Aziz v. Catalunyacaixa, CJEU 14 March 2013, ECLI:EU:C:2013:164. On strategic litigation in European private law, see further Kas (2019).
} 
included in the rule-making process (Mak, 2018). According to Fraser's theoretical approach, an entitlement to equal participation depends on the demarcation of the 'who' under the all-subjected principle. An overarching governance regime needs to be identified in order to be able to indicate subjects (Fraser, 2014, pp. 152-153) ( $^{5}$ and the understanding of the structure of EU governance is notoriously complex.

Given the multilevel structure of the European legal framework, the democratic basis for governance is fragmented. In the absence of a fully European government, governance regimes may be found at the national level of the Member States and at the EU level. The two may be linked through the concept of citizenship, insofar as citizens of Member States obtain a similar status at the EU level Habermas speaks of 'dual citizenship' (Habermas, 2012, pp. 36-37, referring to A. von Bogdandy). European citizens in this view are engaged in decision-making processes both through national and European democratic proceedings. This conceptualisation of the interrelation between the national and the European level provides a framework for democratic deliberations on shared ideas of justice at the national and European levels (Mak, 2012).

While citizenship may provide a point of reference for developing the 'what' and 'how' of justice, it may, however, inadvertently limit the scope of 'who' is involved in decision-making processes in a transnational context. This is particularly relevant in the case of development projects, such as those examined by Bhatt and Lander, in which the possibilities to participate in decision-making are shaped through private legal constructs relating to the negotiation of investment contracts. In the first place, a characteristic of private legal relationships is that one does not have to be a citizen to enter into such legal interactions. Someone with a foreign nationality may just as well conclude a mortgage contract with a bank in Spain as a Spanish citizen. And international investment companies do not need citizenship to influence the shaping of contractual regimes to their benefit. In the second place, minorities may be overruled by powerful business lobbies. While indigenous communities in, for instance, Australia (Bhatt, 2020, pp. 10-12, 174-181) or Mongolia (Lander, 2020, pp. 39-41; Bhatt, 2020, pp. 125-126, 181-183) may enter into agreements with international investors, they are hardly heard in the process of enacting a legal framework for the conclusion of such contracts. A reference to their citizenship may then give them a formal say in the process, but would not guarantee substantively equal participation. A demarcation that is solely based on a formal notion of citizenship would, therefore, probably be too restrictive and would not be in accordance with Fraser's all-subjected principle.

In line with Fraser, one might argue that elements of an overarching governance structure can be found in elements other than citizenship. She submits that an overarching regime of global governance to which everyone is subject exists and comprises two key components (Fraser, 2014, p. 153). In the first place, this regime is founded in a capitalist world system that is based on private-property rights and promotes profit-seeking businesses. In the second place, it goes back to the idea of an interstate system based on mutual recognition of equal sovereign states, even though this system is slowly being replaced by a compound of international law and non-state governance structures. Although, in Fraser's opinion, there may still be wild zones under such a global-governance regime, the overarching structure would provide the starting points for institutionalisation at lower levels, which would guarantee the participation of all subjected under the global regime (Fraser, 2014, p. 153).

While this view solves some of the abovementioned problems, it raises new issues. For European private law, for instance, this view has the advantage of abstracting from the notion of citizenship. At the same time, it seems to strengthen the economically oriented background of EU contract law, likely at the expense of other ideas of justice. Rather than challenging the status quo, it might entrench it. These concerns seem all the more pressing for the transnational investment cases discussed by Bhatt and Lander, in which the strong emphasis on capitalist ideals lies at the basis of problems related to equal participation. A legal framework that facilitates transnational projects set out by powerful

\footnotetext{
${ }^{5}$ Unlike the all-affected principle, the all-subjected principle can only apply in the case in which a governance structure is in place to which people can be subjects.
} 
companies is unlikely to offer many starting points for the participation of individuals and communities who seek protection of non-economic interests. Imagining an overarching governance regime in capitalist terms may serve the demarcation of the 'who', but it may to some extent compromise the 'what' and the 'how' of transnational justice.

\section{World maps}

Including wild zones of globalisation in a transnational legal order that is governed by rule-of-law standards, in conclusion, requires a combined theoretical and empirical approach. The theoretical insights developed by Fraser and Habermas offer inspiration, but do not perfectly fit the reality of private legal relationships in transnational constellations. Fraser's all-subjected principle may provide a starting point for establishing who should be included in decision-making processes. In transnational contract negotiations, however, it seems difficult to define who is and should be included in decisionmaking on the basis of (dual) citizenship. Such an approach may be too restrictive, as it would exclude interested parties who do not have the relevant citizenship regarding the project that is at stake. Furthermore, even if these parties had citizenship, their voices might not be equally heard in comparison to those of strong business lobbies and equal participation in decision-making processes could not be guaranteed through (formal) citizenship. Fraser's construction of an overarching governance regime to which everyone is subjected, on the other hand, may be too expansive, insofar as it allows everybody a say in whether to regulate wild zones of globalisation without specifying how this should be arranged. More problematically, her conceptualisation of the overarching regime has its basis in the capitalist world order itself. Even if the existence of an overarching global-governance regime is accepted, it thus seems unlikely that changes in the current lack of equal participation can be achieved under this structure. ${ }^{6}$

Contrasting these theoretical perspectives with Bhatt's and Lander's views on transnational legal ordering, nevertheless, is helpful to obtain a better understanding of where to locate rule-of-law problems. Fraser's reframing of the political space in which decision-making takes place - from the national to the transnational - predicts the occurrence of local gaps or wild zones in which regulation is lacking. As such, it provides a slightly different view on the same phenomenon that both Bhatt and Lander study, namely the extent to which fragmentation of rules leaves room for powerful private actors to shape the legal framework for their transactions according to their own interests. An advantage of Fraser's framing is that it includes all potential sites of private actors' law-making - even those in which potential clashes of power are still dormant. A disadvantage is that it remains highly abstract and may not be able to exactly pinpoint where and how private actors shape the law.

More empirical research such as that conducted by Bhatt and Lander is needed to understand what is happening on the ground and where improvements may be made. Both Bhatt and Lander provide indispensable empirical insights into the contractual practices surrounding transnational development projects. They show how the negotiation of seemingly technical contract clauses benefits the interests of investors at the expense of local communities, and how little those communities get to say during the negotiation process. In this way, they make visible how the interaction between multinational companies, state authorities and local communities shapes the legal framework for transnational development projects. To the extent that powerful private actors obtain a constitutional role in shaping the legal system, it does not seem too far-fetched to extend the rule of law to their actions. In particular, as regards equal participation in decision-making for all subjected to a certain governance structure, current practices do not seem to live up to the standard, as they impede the full participation of less powerful actors. Where Bhatt's and Lander's books map shortcomings in regard to equal participation in light of the rule of law, they also mark points of reference for possible change. ${ }^{7}$

\footnotetext{
${ }^{6}$ In fact, Fraser herself advocates for the creation of new global representative institutions; Fraser (2008, p. 70).

${ }^{7}$ Bhatt makes specific suggestions in Chapter 8 of her book, and Lander sees the Mongolian experience as a lesson for other jurisdictions (2020, p. 251).
} 
Conflicts of Interest. None

Acknowledgements. The author would like to thank Kinnari Bhatt, Jennifer Lander and Sanne Taekema for two lively Zoom meetings on the theme of private actors and the rule of law, which helped to shape the argument of this paper.

\section{References}

Bhatt K (2020) Concessionaires, Financiers and Communities: Implementing Indigenous Peoples' Rights to Land in Transnational Development Projects. Cambridge: Cambridge University Press.

Caruso D (2015) Qu'ils mangent des contrats: Rethinking Justice in EU contract law. In Kochenov D, de Búrca G and Williams A (eds), Europe's Justice Deficit? Oxford: Hart, pp. 367-378.

Collins H (2014) On the (in)compatibility of human rights discourse and private law. In Micklitz H-W (ed.), Constitutionalization of European Private Law. Oxford: Oxford University Press.

Colombi Ciacchi A (2006) The constitutionalization of European contract law: judicial convergence and social justice. European Review of Contract Law 2, 167-180.

Domurath I and Mak C (2020) Private law and housing justice in Europe. Modern Law Review 83, 1468-2230.

Fraser N (2008) Scales of Justice. Reimagining Political Space in a Globalizing World. Cambridge: Polity Press.

Fraser N (2014) Publicity, subjection, critique: a reply to my critics. In Nash K (ed.), Transnationalizing the Public Sphere. Cambridge: Polity Press.

Habermas J (2012) The Crisis of the European Union: A Response. Cambridge: Polity Press.

Halliday T and Shaffer G (2015) Researching transnational legal orders. In Halliday T and Shaffer G (eds), Transnational Legal Orders. Cambridge: Cambridge University Press, pp. 475-528.

Hesselink MW (2015) Democratic contract law. European Review of Contract Law 11, 81-126.

Józon M (2020) Judicial governance by unfair contract terms law in the EU: proposal for a new research agenda for policy and doctrine. European Review of Private Law 28, 909-930.

Kas B (2019) Transforming the European 'legal field' by strategic litigation: a research agenda. In de Almeida L et al. (eds), The Transformation of Economic Law. Oxford: Hart, pp. 347-366.

Lander J (2020) Transnational Law and State Transformation: The Case of Extractive Development in Mongolia. London: Routledge.

Luzak JA and Mak V (2014) The consumer rights directive. In Sieburgh C et al. (eds), De invloed van het Europese recht op het Nederlandse privaatrecht. Deventer: Kluwer, pp. 67-92.

Mak C (2012) Europe-building through private law: lessons from constitutional theory. European Review of Contract Law 20, pp. 338-339.

Mak C (2018) First or second best? Judicial law-making in European private law. In Mendes JM and Venzke I (eds), Allocating Authority. Oxford: Hart, pp. 217-240.

Pistor K (2019) The Code of Capital: How the Law Creates Wealth and Inequality. Princeton: Princeton University Press.

Rajah J (2015) 'Rule of law' as transnational legal order. In Halliday T and Shaffer G (eds), Transnational Legal Orders. Cambridge: Cambridge University Press, pp. 340-373.

Reich $\mathbf{N}$ et al. (2014) European Consumer Law. Cambridge/Antwerp: Intersentia.

Tuori K (2014) On legal hybrids and perspectivism. In Maduro M, Tuori K and Sankari S (eds), Transnational Law: Rethinking European Law and Legal Thinking. Cambridge: Cambridge University Press, pp. 11-57.

Van Duin JML (2017) Metamorphosis? The role of Article 47 of the EU Charter of Fundamental Rights in Cases Concerning National Remedies and Procedures under Directive 93/13/EEC. Journal of European Consumer and Market Law 6, pp. 190-198.

Cite this article: Mak C (2021). Mapping 'wild zones' of globalisation: on private actors and the rule of law. International Journal of Law in Context 17, 107-113. https://doi.org/10.1017/S1744552321000045 